\title{
A formação em obstetrícia: competência e cuidado na atenção ao parto
}

\author{
Obstetric training: competence and care in birth assistance
}

Esta tese consiste em uma análise da formação em obstetrícia durante a graduação em Medicina, baseada em pesquisa etnográfica realizada em duas escolas conceituadas, localizadas na cidade de São Paulo. A proposta foi estudar o modo como se articulam a competência técnica e científica e o cuidado ou relação com a paciente no ensino teórico e prático da assistência ao parto. As técnicas utilizadas na coleta de dados incluíram observação participante, entrevistas semiestruturadas e, de modo complementar, a análise de livros-textos e protocolos assistenciais. $\mathrm{O}$ trabalho abrangeu uma caracterização das propostas curriculares e um exame da experiência dos alunos quanto ao ensino teórico e prático, incluindo sua supervisão nas diversas atividades assistenciais. A ênfase maior recai sobre o desenvolvimento de conhecimentos científicos na formação. Mesmo no internato, maior relevo é dado à aprendizagem da construção e encenação de narrativas clínicas, privilegiando-se a transmissão oral do conhecimento e a memória em relação ao registro escrito e à consulta ao prontuário das pacientes. Pautado em parte pelas chamadas concepções "clássicas", que sustentam uma visão patológica da fisiologia do parto, o exercício da prática envolve condutas que têm sido questionadas com base nas evidências científicas ou até abandonadas em outros contextos. As decisões acerca de condutas ou tratamentos adotados não são compartilhadas com as mulheres atendidas que,

freqüentemente, não são consultadas ou sequer informadas a respeito. Por vezes, juízos de valor também influenciam o julgamento clínico e a tomada de decisão médica. Há poucos parâmetros para se avaliarem as atitudes dos alunos em sua interação com as pacientes. Nos serviços em que há maior interação entre alunos e pacientes, a supervisão é menor. Existem acordos informais, entre os assistentes, na divisão de plantões, que se contrapõe aos organogramas formais dos serviços obstétricos vinculados às Faculdades de Medicina pesquisadas. Esses acordos subordinam os objetivos institucionais da boa formação e assistência em obstetrícia aos interesses individuais e coletivos dos profissionais obstetras responsáveis pela supervisão do ensino.

Componentes do currículo oculto, esses acordos servem de modelo para outros envolvendo residentes e/ou alunos. Ao longo da formação dos estudantes de Medicina, as interações entre os sujeitos em relação no exercício do ato médico contribuem de diversas maneiras para desqualificar a prática médica da obstetrícia como técnica moral-dependente.

Sonia Nussenzweig Hotimsky Tese (Doutorado), 2007 Departamento de Medicina Preventiva, Faculdade de Medicina, Universidade de São Paulo, SP. sonianhotimsky@uol.com.br

Texto completo:

http://www.teses.usp.br/teses/disponiveis/5/

5137/tde-14112007-082030/ 